\title{
Pressure Tubing Device
}

National Cancer Institute

\section{Source}

National Cancer Institute. Pressure Tubing Device. NCI Thesaurus. Code C50239.

Flexible tubing designed to withstand high pressure. 